\title{
Barriers Preventing to Reap the Benefits of E-commerce in Libya Prior and During COVID-19 Pandemic
}

\author{
* Ragab Ihnissi ${ }^{\mathrm{a}}$, Alhadi Klaib ${ }^{\mathrm{b}}$
}

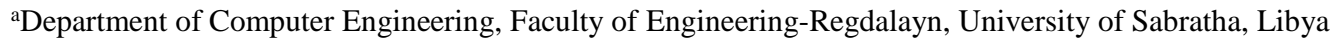
${ }^{b}$ Department of Computer Science, Faculty of Information Technology, University of Elmergib, Libya

\section{Keywords}

Barriers

Benefits

COVID-19 pandemic

E-commerce

Libya

\begin{abstract}
A B S T R A C T
In Libya, there are a various barrier to developing e-commerce, and the COVID-19 pandemic has emphasised the importance of overcoming these hurdles in the shortest possible timeframe. This paper stems from a review of the studies which have focussed on the obstacles which preclude Libya reaping the benefits of e-commerce, at a time when many businesses are moving online, as a result of the lockdown introduced in response to COVID-19. This study has discussed and inspected the problems facing Libyan e-commerce. As a result of these problems, e-commerce has not taken hold in Libya or brought the country its considerable economic advantages. This paper suggests a range of recommendations which will contribute to adopt e-commerce in Libya and advance its popularity, among individuals, organisations and the government institutions, so that Libyan society can begin, and continue, to benefit from e-commerce.
\end{abstract}

العو ائق التي تحول دون جني فو ائد التجارة الإلكترونية في ليبيا قبل و أثناء جائحة COVID-19

$$
\begin{aligned}
& \text { *رجب بشير حنيش 1 و الهادي علي كليب2 } \\
& \text { 1قسم هندسة الحاسوب، كلية الهندسة - رقدالين، جامعة صبراته، ليبيا } \\
& \text { 2قسم علوم الحاسب، كلية تقنية المعلومات، جامعة المرقب، ليبيا }
\end{aligned}
$$

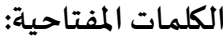

العوائق

الفوائد

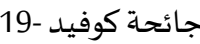

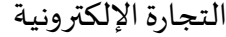

ليبيا
الملخص | (المص

في ليبيا، هناك عوائق مختلفة أمام تطور التجارة الإلكترونية، وقد أكدت جائحة COVID-19 على أهمية التغلب

على هذه العقبات في أقصر إطار زمني ممكن. تنبع هذه الورقة من مراجعة الدراسـات التي ركزت على العقبات التي

تمنع ليبيا من جني فوائد التجارة الإلكترونية، في الوقت الذي تنتقل فياء العديد من الشركات والمؤسسات عبر

الإنترنت نتيجة الإغلاق الذي تم اتخاذه استجابةٍ لـCOVID-19. ناقشت هذه الدراسة وبحثت المشاكل التي تواجها

التجارة الإلكترونية الليبية. نتيجةٍ لهذه المشاكل، لم تترسخ التجارة الإلكترونية في ليبيا أو جلبت للبلاد مزايا

اقتصادية كبيرة. تقترح هذه الورقة مجموعة من التوصيات التي ستسهم في تبني التجارة الإلكترونية في ليبيا

وتعزيز شعبيتها بين الأفراد والمنظمات والمؤسسات الحكومية ليتمكن المجتمع الليبي من البدء والاستمرار في لئي

الاستفادة منها.

\section{Introduction}

The outbreak of the coronavirus has resulted in people being obliged not to come into close proximity to others, and this new reality has led to many companies moving their businesses online and turning to ecommerce to generate profits. E-commerce encourages people to

*Corresponding author:

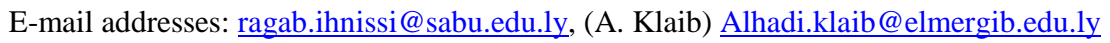


avoid coming into contact with others and spreading infection. It also saves jobs and can make it easier for the population to reconcile themselves to extended periods of social distancing [1]. Libya is a growing nation, and like other expanding communities, it has introduced lockdown measures in response to the spread of COVID19. This being the case, consumers are obliged to depend more heavily on e-commerce platforms, to access their essential requirement.

Lockdown regulations have obliged people to work, socialise, communicate, and carry out their job roles from home. The utilization rate of internet services has a sharp rise, from 40 per cent to 100 per cent, when comparing current and pre-pandemic levels. Zoom, the video-conferencing service, reports a 10-fold increase in usage, while the use of content-conveyance services, such as Akamai, have also a rise of 30 per cent [2].

The term e-commerce describes business-related transactions which take place across the internet. It has been known as the production, promotion, distribution of products and sale by using telecommunication networks by the World Trade Organisation (WTO) [3].

Everyday life in Libya has been significantly affected by the pandemic and subsequent lockdown, and this in turn has pushed the demand for e-commerce. However, Libya must tackle a certain deficiencies and issues for e-commerce to grow: at present it lacks digital skills, has a poor Information and Communications Technology (ICT) infrastructure, and an underdeveloped system for online purchasing. All these areas were looking at before the pandemic broke out, but COVID-19 has added an element of urgency and made it clear that ecommerce will not fully flourish in Libya unless these issues are resolved.

Only 22 per cent of the Libyan population use the internet and online shopping is not widespread. The UN's trade section, UNCTAD, stated that, in 2017, a low 15 per cent of adults and 23 per cent of all internet users in Libya made an online purchase [4]. This indicates that ecommerce websites find themselves in a difficult position and must find a way of overcoming these obstacles to expansion.

To create a comprehensive picture of the problems associated with ecommerce in Libya, this study focusses on the current status and challenges which are facing Libyan e-commerce that increased due to the COVID-19 pandemic.

\section{Study Objectives}

This study sets out to clarify the current position, benefits and challenges faced by e-commerce in Libya. The study has a few specific objectives, namely:

- To estimate the present position of e-commerce in Libya.

- To pinpoint the established benefits of promoting large-scale ecommerce in Libya.

- To recognise the challenges which are being faced by e-commerce in Libya.

\section{Research Methodology}

This research has been founded on a qualitative approach (secondary data) taken from published websites, reports, official statistics, newspapers, magazines, research papers, journals, and books.

\section{Review of Literature}

There is a vast body of literature on e-commerce, which looks in detail at how it has succeeded in developed and some developing countries. Nevertheless, there is little available studies on e-commerce in Libya.

\section{E-commerce Importance}

The introduction of social distancing, as well as travel limitations in the wake of the coronavirus pandemic, have led to the closure of many commercial and retail outlets. As a result, many businesses have gone online and concentrated on their e-commerce activities [5].

While the e-commerce and internet alike are exceedingly associated with developed countries, e-commerce could bring significant benefits to the economies of developing countries if it is managed and organised effectively. [6]. In essence, e-commerce is a relatively new approach to purchasing, selling or interchanging information, goods and services through the internet [7]. E-commerce technologies can upgrade business processes and raise efficiency levels if they are implemented correctly. To date, developing countries have not seen positive results from harnessing e-commerce technologies [8]. This is because e-commerce, which is the result of applying the internet to business, is totally dependent on information infrastructures and telecommunications to function and expand [9].

As the internet and other global online networks have grown and spread, this has brought new business opportunities for e-commerce, and established new national and global business relationships.

As a result, this has led people viewing e-commerce and e-banking as an unavoidable form of financial services. E-commerce allows customers and dealers to interact on a shared platform and quickly carry out business without in any way diluting individual demands and the relationships which exist between those involved [7].

\section{E-commerce Barriers Prior and During the Coronavirus Pandemic}

Prior to the outbreak of COVID-19, companies which ran into issues with their online platform, such as technical difficulties, consumer protection issues, cybercrime, or a drop in confidence and trust on the part of consumers, could simply revert to selling from their stores. At present, this option is not available, so businesses have to tackle these issues rather than ignore them, if they are to survive.

In Libya, e-commerce may well enjoy a degree of success either during or after the COVID-19 pandemic, it has yet to overcome several major barriers as described below.

\section{a) Technical barriers}

E-commerce takes place online and websites are the internet platforms where sellers meet purchasers

Technical limitations are hurdles in countries which are trying to promote and grow e-commerce. People cannot access the internet with inadequate technology, infrastructure and IT services, so if ecommerce is to develop, technical barriers must be overcome [10] Certain developing countries have weak connections and slow internet speed, and this prevents companies and individuals from building an appealing and efficient online website, either because the website freezes or takes a time to payload, or because customers cannot access it [11].

Connectivity problems are common in the Middle East and act as a brake on developing e-commerce [12]. As a result, e-commerce remains in its early stages in Libya, when compared with e-commerce activity in the developed countries [13].

Online businesses must have well-designed apps or websites, which work efficiently and are attractive to consumers, if they are to be successful [14]. To date, Libya has not established robust systems to support e-commerce and, overall, its websites are not professional or competently designed [15]. The design of a website is key to inspiring customer trust and promoting e-commerce [14]. A good website will have a secure payment system, allow users to move seamlessly from page to page and offer consumers an enjoyable journey which promotes positive purchasing behaviour [16-18].

Websites which have insecure payment systems do not support or encourage e-commerce [19], because they open the door to cybercrimes - a problem exacerbated by the lack of robust anticybercrime legislation [20].

E-commerce first began to make inroads in the Middle East and North Africa (MENA) zone, where Libya is located, back in 2005. This is comparatively late, given that the global move towards embracing ecommerce began far earlier [21]. The present pandemic has seen a shift towards online shopping on the part of customers, and this has placed additional pressure on e-commerce websites and multiplied the technical problems they were already facing [22]. This has, in turn, also emphasised the need for Libyan government and the merchants to support and invest in e-commerce.

b) Trust and Confidence Barriers 
Confidence and trust lie at the heart of all business and are key elements of the trade. If customers do not have confidence in ecommerce websites, and cannot turn to reviews or find information to inform their decisions, they will hesitate to use an e-commerce platform [23]. An absence of trust makes it virtually impossible to grow an online presence. Most businesses depend on referrals or actual physical experiences to attract and hold on to customers. Consumers are reluctant to take part in any business dealings which are not based on, or inspire, trust [24]. The absence of face-to-face interactions on e-commerce platforms only serves to make trust a key factor in ecommerce.

Trust is vital in shaping consumer behaviour and locates whether or not online shopping will grow in Libya. If consumers do not trust or feel confident in online shopping, it is highly unlikely that e-commerce will ever be accepted by the majority of consumers in Libya, or viewed as an acceptable, desirable alternative to traditional business strategies [25].

The coronavirus pandemic has undermined trust in businesses. Logistical problems, restrictions and a range of technical problems which were ignored up until now, have resulted in goods not being delivered. It is vital to concentrate on the issue of trust, because there is no future for online commercial businesses if consumers cannot trust producers and retailers [26].

\section{c) Socio-cultural Barriers}

The term culture encompasses the values, traditions, behaviours, beliefs and roles shared by a particular community [27]. Cultural norms are passed down from one generation to the next, as are patterns of behaviour which emerge from people's interactions. Culture defines the way in which a society overcomes issues of trust, knowledge and language barriers, and cultural views are either transmitted or taught. A society's culture has a significant impact on its consumer behaviour [28], namely the views and beliefs which determine how individuals behave and the purchase decisions they make [29]. At present, many developing countries do not encourage e-commerce. Additionally, the lack of trust people have in technology in general and online culture in particular means that the conditions for transitioning to e-commerce are not in place. The acceptance and development of e-commerce confronts a major barrier in the socio-cultural characteristics of developing nations and faces major obstacles in persuading these countries to accept the concepts which are integral to online transactions [30]. In addition, religion plays a key role in many countries and influences consumer attitudes and behaviour. This is particularly true of countries in the developing world where Islam is the state religion. Islam rejects any businesses which include gambling, non-halal products, the paying of interest and standard insurance services, and these rules could affect all businesses including e-commerce [31].

Furthermore, e-commerce is negatively impacted by two further barriers: lack of digital literacy and language issues [32, 33]. It has been argued that lower rates of internet penetration, and thus ecommerce - derive from poor knowing of the English language. This problem is affecting 50 per cent of the population of developing countries [34, 35]. In addition, it was found that a lower use of broadband, and thus limited access to e-commerce websites and channels were directly connected to digital illiteracy, particularly in rural environments [36]. The adoption of e-commerce has been set back by the introduction of COVID-inspired barriers to personal contact, since individuals in developing countries such as Libya traditionally enjoy having a personal relationship with retailers and traders [37]. In summary, the coronavirus pandemic has had a negative impact on business in general, as well as consumers in Libya.

\section{A Threat of Cybersecurity to E-commerce}

As increasing numbers of people are coming to depend on digital resources, some of whom have no previous experience of the digital world, incidents of fraud and scams are also growing [38]. The steep upward rises in the number of people using digital technologies has led to an increase in online fraud, security breaches, scams, and loss of personal information. The current pandemic has introduced uncertainty, and fraudsters are taking advantage of the crisis by extorting money or stealing information or by introducing technological vulnerabilities [39]. Experts state that this period of insecurity has seen a significant rise in malware, ransomware and phishing attacks [40].

Cybersecurity sets out to protect internet-linked systems (such as data, software, and hardware) from cyberthreats. Individuals and organisations alike turn to cybersecurity experts to prevent unauthorised people from accessing their data and computerised systems [41].

Since the beginning of the COVID-19 pandemic, malware and scams attacks have crucially increased [42, 43], and phishing has risen by 600 per cent, as of March 2020 [44]. In April 2020 alone, Google is said to have blocked 18 million malware and phishing emails linked to the virus every day [45]. Even massive companies such as Facebook have recently discovered that their systems were breached [46]. In addition, detrimental force offensives on the Microsoft Remote Desktop Protocol (RDP) systems have also risen [47]. It is now clear that cybersecurity is unable to guarantee companies a safe digital ecosystem - a situation which has not been helped by the pandemic, since more people are using the internet for shopping and entertainment [48]. Governments would be well advised to make every stakeholder, from the end user to internet service providers, responsible for their own cybersecurity [49]. E-commerce cannot function unless users protect their personal information and payment details. Consequently, cybercrime must be avoided, and online transactions are to be secure, by making cybersecurity more effective. The MENA region has not remained immune to cyberattacks, and cybercriminals are taking advantage of the governments' focus on controlling the pandemic, to extend their activities [50]. Egypt is the only country in North Africa to have passed legislation relating to cybercrimes and the protection of important infrastructures, while Morocco is currently drawing up laws to tackle this issue. Neither Libya nor Western Sahara have taken any steps to neutralize cybercrimes [51].

Africa is particularly vulnerable to cyberattacks, because it lacks legislation to tackle this threat and the number of crimes is underreported. In 2000, 564 cybersecurity incidents were noted, and this number rose to 18,607 by 2011 [52]. By 2016, Africa was the target of 24 million malware attacks, and the following year spam emails, botnets, malware, and pirated software. In addition, other crimes were regularly being reported right across Africa [53].

Africa's systems are open to cyberattacks because cybersecurity is not rigorously enforced. The Business Software Alliance stated that, in 2017, Libya and Zimbabwe had the highest software piracy rates globally, with 90 per cent and 89 per cent, respectively, of the software used in those countries being unlicensed [54]. In view of the fact that unlicensed software cannot get any updates from the manufacturers, its very existence speeds up the rate at which malware is spread [53]. The researchers found very few studies in the literature on e-commerce which dealt with the obstacles facing Libya in relation to e-commerce [55]. Of course, e-commerce is just beginning to develop in Libya [13].

\section{The Current Situation for Libya E-commerce}

The pandemic of COVID-19 led to a steep rise in demand for ecommerce in Libya. Nevertheless, e-commerce did not take off, either now or in the past, because of several issues which remain to be resolved in Libya: infrastructural, economic, and legal. Although 3G and $4 \mathrm{G}$ technology were introduced to the country, and more people could therefore access the internet, this did not lead to a fast expansion of e-commerce. Most recent data shows that, in January 2020, the Libyan internet penetration had reached 75 per cent, comprising 5.1 million internet users [56]

The majority of Libyan internet users (63 per cent) access the internet through their mobile phones, and work and home computers come next in the list of most used devices. Nevertheless, home internet remains expensive, and this means that people who live outside the main urban centres, and those on a low wage, cannot use it, either for geographical or financial reasons. Universal access will only come to Libya when the whole population is computer literate, for elderly 
individuals and women tend to have low levels of computer literacy to this day [57].

The coronavirus pandemic had a negative impact on everyday life in Libya. People have less money to spend and weaker purchasing power now that the cost of living has risen sharply. E-commerce remains beyond the reach of most Libyans, who have turned to the black market in large numbers, to secure goods and services which are not available through normal business channels.

Many companies, and government institutions have created and uploaded websites, to offer information about what they do, and list their services and products.

The number of e-commerce sites in Libya remains small. Wecard and Libyan Spider are among the better-known websites and, in collaboration with Amazon UK, enable customers to pay for online goods in Libyan dinars and provide delivery within Libya [57].

The major reason for the low transactions of e-commerce is unavailability of a legal framework for guaranteeing the security of electronic business and financial transactions. In addition, there is a widespread belief that e-commerce transactions are neither secure nor reliable.

\section{E-commerce Benefits}

E-commerce provides a range of benefits and opportunities for customers and merchants. Customers can benefit from the ecommerce features are following:

1. During the pandemic lockdown, customers can shop round the clock, and access global markets from wherever they may be, without being obliged to meet sellers in person.

2. E-commerce simplifies comparing prices and finding the same goods for the cheapest price, thereby reducing costs for the customer.

3. Customers can leave feedback around a product and read what others have written before deciding to buy.

4. E-commerce makes it possible for people to buy or sell services and goods from home, thereby reducing the number of people congregating in markets and the likelihood of spreading coronavirus.

5. E-commerce encourages the setting up of small and medium-sized companies. These can access the global market and are not expensive to establish. It therefore provides opportunities for people to become self-employed.

6. Records of transactions - both sales and purchases - are saved in the customer's login ID, these are easy to retrieve and review.

The main e-commerce benefits for traders are included:

1. The benefit of e-commerce is that traders can expand from the native to the global market at minimal cost. In this way, traders and companies can quickly target a larger market and appropriate, effective partners in a simple way.

2. Traders who sell online no longer require intermediaries between themselves and costumers.

3. Transport costs are lower, particularly when it comes to digital products such as computer programs, which can be directly transferred across a network [58].

4. E-commerce traders can start with far lower costs than opening or running a conventional store.

5. Traders of e-commerce can track and analyse consumers purchasing behaviour and customise their goods and services to meet customer needs.

6. E-commerce can be a lifeline for small businesses suffering because of the lockdown, since e-traders do not have to pay any form of overheads (such as rent, business rates).

\section{Barriers to Libya e-commerce}

The e-commerce growth is restricted by many of the same limitations and problems which we see in the developing countries, particularly in Libya. Although, the benefits of e-commerce are evident and well documented. The Libyan state continues to face major issues, which are hampering the development of e-commerce, such as:

1) Infrastructure Obstacles

\section{a) ICT Obstacles}

Over the last years, Libya has put in an ICT infrastructure which is adequate in the short-term, rather than designed to meet the country's long-term communication needs.

At present, it is expensive for Libyans to set up and use broadband. While subscription fees are high, when compared with those charged in neighbouring Egypt and Tunisia. Since broadband subscriptions are expensive, rural communities, where wages are low, can often not afford to cover the costs. In addition, broadband is only available in larger urban centres, where demand is outstripping supply, and smaller towns and villages cannot access these services. Overall, the broadband available in Libya is not reliable, and disconnects at regular intervals. While its download speeds are far lower than those promised by the provider.

The pandemic has emphasised the importance of finally closing the digital divide between urban and rural areas in Libya. E-commerce has had a significantly affirmative effect on the economies of developed countries during the pandemic. It is high time for Libya to follow suit and bring in reliable and inexpensive ICT services for the whole population.

\section{b) Postal Services Obstacles}

Prior to establishing e-commerce, Libya needs to set up a postal delivery service, which is both efficient and fast. Problems with postal codes, distribution and delivery methods will create obstacles to ecommerce. Tackling issues with the postal service, therefore, need to be prioritised.

\section{c) Electricity Supply Obstacles}

If e-commerce is to expand and thrive in Libya, the power outage problem which affects individuals, businesses, and organisations in the country must be resolved. At present, the electricity supply in Libya remains unreliable and erratic. This is one of the major obstacles facing e-commerce. Neither e-commerce nor ICT services can function smoothly nor dependably if the electricity supply is irregular. The Libyan electricity supply has had a negative impact on measures being taken to contain the pandemic. For example, the daily outages have made it impossible for hospitals to function, run ventilators and use vital medical equipment.

\section{2) Technical Obstacles}

A range of technical problems are creating obstacles to effective ecommerce in Libya, namely:

1. Too few technical experts and trained staff in Libya, who can run e-commerce websites, with a view to support the commercialism business model.

2. Web sites design and technical back-up for e-commerce is extremely expensive in Libya.

3. The existing e-commerce websites have not been well-designed, and do not allow customers to pay for goods or services by credit card, since Libya is not connected to international banking networks. These e-commerce websites are therefore limited to acting as a window for goods, and list where they can be bought and the price. Social media sites are also used to promote products.

4. As noted earlier, there is widespread software piracy in Libya, and the use of unauthorized software only serves to facilitate and increase the diffusion of malware.

5. Security systems remain inadequate, and this undermines customers' confidence in the electronic commercial transaction process.

\section{3) Legal Obstacles}

In November 2016, the cybersecurity company Symantec, in collaboration with the African Union Commission (AUC), presented a report on cybersecurity in the 54 countries in Africa. The report found that 30 of these countries (including Libya) did not have the legal tools needed to combat cybercrime and process and manage 
electronic evidence. This lack of a suitable legal infrastructure and legislation drawn up to support cybersecurity are a major obstacle to expanding e-commerce in Libya. Areas which need to be legally addressed include the rights of providers, the protection of users, directives on bank transfers, e-payments, piracy, electronic theft, and fraudulent activities.

\section{4) Cybersecurity Obstacles}

The huge rise in e-commerce activity has produced fresh issues relating to cybersecurity, including:

- At present, Libya has not introduced or implemented cybersecurity measures. In addition, legislation to classify and safeguard personal data and payment information has yet to be passed. This is due to the major challenges currently posed by political insecurity and national defence issues in Libya. Limited budgetary resources are also an important factor.

- The Libyan government, financial institutions, companies, and individuals all lack sufficiently high levels of knowledge and awareness of the nature of e-commerce.

5) Socio-cultural Obstacles

If e-commerce is to expand and be accepted in Libya, important cultural and social challenges have to be taken into account. These include:

1. Developing countries such as Libya, which wish to expand ecommerce, must overcome socio-cultural obstacles. These include the traditional view that the local market is the ideal location for socialising, shopping, and leisure.

2. Libyans enjoy interacting with others, face to face, rather than using technology and the internet to communicate. The relationships customers establish with retailers and vendors are key to building business connections based on trust.

3. Libyan consumers and retailers alike prefer buying and selling through traditional stores, which customers can visit, to look at, feel and handle products prior to deciding what to buy. This behaviour is at odds with e-commerce.

4. A cash-based economy in Libya is remain predominant. Thus, the notion of cash on delivery is merely another version of paying for goods in store. Reluctance to move away from cash also springs from the lack of trust consumers have in online payment systems.

5. Arabic is the main language used in Libya, but it is not supported by international e-commerce systems. As a result, Libyans who wish to make online purchases can find it difficult to search and use global e-commerce systems.

The coronavirus pandemic has amplified these obstacles (Except last one) and emphasised the importance of surmounting them as a matter of urgency, because play a crucial character in spreading epidemic. If the virus is to be crushed, e-commerce has a vital part to play in the battle, and it therefore needs to be encouraged, so that it continues to function during periods of lockdown.

\section{6) Trust and Confidence Obstacles}

Trust is a key element in the virtual globe, even more than in the veritable globe. Since customers and vendors are separated by geographical distance and do not have an opportunity to see or speak to each other in real time.

As highlighted above, there is widespread mistrust of e-commerce among Libyans, and this is a massive hurdle to the acceptance and ecommerce expansion in the country.

\section{Recommendation and Solutions}

This paper recommends that the Libyan government and business organisations should adopt several measures, listed below, with a view to upholding the e-commerce growth and implement a fast and reactive e-commerce system in Libya:

1. The Libyan government needs to upgrade the ICT infrastructure and broadband capacity in the country, by ensuring that all areas of Libya have broadband coverage, and that broadband speed is fast and reliable. Experts must be charged with monitoring developments in new technology and checking that the ICT system is kept up to date.

2. Another obstacle to the e-commerce widespread use in Libya is the ICT low level skills across the country. Therefore, the whole society should be provided with both official and unofficial ICT training.

3. The Libyan government must provide government institutions, companies and individuals with reliable, accessible, and inexpensive ICT services and electricity supplies.

4. Websites are important elements of e-commerce and must be designed in a way which appeals to consumers, ensures high levels of security for personal and financial information, and provides a user-friendly shopping experience. Customers will begin to trust e-commerce transactions, and explore what is available online, if their website browsing experience is positive and inspires trust.

5. At present Libyans favour shopping in physical stores and it will need a large-scale advertising campaign, across social media, TV channels and the radio, to break down this cultural barrier to ecommerce. Multimedia advertising can be harnessed to present online shopping as an excellent alternative to physically go to stores or the market, by emphasising that e-commerce has a range of benefits and it is quick, simple, and trustworthy.

6. The government of Libyan should draw up and pass legislation which protects consumers who are making electronic transfers, and tackles cybercrime, to safeguard individuals, as well as the government and businesses. E-commerce will benefit from these measures. Consumers will feel more confident shopping online if they have legal redress and protection, and the Libyan economy will benefit from the growth of e-commerce.

7. The government of Libyan should raise public and business awareness of the steps which can be taken to protect individuals and organisations against the threats posed by cybercrime. The COVID-19 epidemic has resulted increasing use of e-commerce. Thus, extremely important to ensure that internet users are fully aware of what to look out for, and how to avoid becoming a victim of cyberthreats.

8. The majority of Libyans access to the Internet by using their mobile phones. Therefore, Libyan government should act and provide users with the possibility of using mobile electronic payments to solve the problem of insufficient cash in banks.

9. The Libyan government must work together with the worldwide e-commerce system and ensure that the Arabic language is included on their websites of e-commerce.

\section{Conclusion}

This research set out to determine the benefits and challenges facing Libya e-commerce within the COVID-19 crisis. Libyan e-commerce is facing a wide range of issues which need to be resolved, and that the country is falling behind in the race to keep up with technology.

As discussed above, the COVID-19 pandemic has highlighted factors which are hampering the developing countries such as Libya to develop their e-commerce. E-commerce will not grow in Libya until various issues are resolved. These include the lack of robust leadership policies and regulations, the absence of banking amenities essential to e-commerce (for example, credit cards), an inadequate infrastructure, technical shortcomings, cybersecurity, trust, and confidence issues. In addition, the lack of essential IT skills and insufficient knowledge and appreciation of the benefits which e-commerce can offer.

If the Libyan government demonstrates the desire to tackle the obstacles that preventing to adopting e-commerce, then the Libyan economy can benefit from the growth of this commercial sector. The numeral of mobile phone users has seen a huge increase in Libya, along with rising internet usage. These two indicators are extremely positive for the e-commerce future. The recommendations and suggestions are mentioned above can enhance the adoption of ecommerce in Libya.

Future studies can build on the findings in this paper and added to its conclusions, by undertaking empirical research focussing on the business sector, to determine its plans for digitisation. In addition, this paper opens the door to further studies to assess the outcomes of implementing the recommendations we have put forward, as and when 
they occur. Long-term research will need to be carried in this field, since the challenges and opportunities associated with e-commerce are of vital importance to the Libyan economy.

\section{References}

[1]- Christoph, U., Alberto, P., Martin, M., and Natasha, R. (2020). "Recommendations to Leverage E-Commerce During the COVID- 19 Crisis. Trade and COVID-19 Guidance Note". World Bank, Washington, DC, https://openknowledge.worldbank.org/bitstream/handle/10986/3 3750/Recommendations-to-Leverage-E-Commerce-During-theCOVID-19-Crisis.pdf?sequence=1\&isAllowed=y, [Accessed: August, 2020].

[2]- Branscombe, M. (2020). "The Network Impact of the Global COVID-19 Pandemic". https://thenewstack.io/the-networkimpact-of-the-global-covid-19-pandemic/, [Accessed: August, 2020].

[3]- WTO,

"Electronic Commerce".

(2020).

https://www.wto.org/english/tratop_e/ecom_e/ecom_e.htm [Accessed: September, 2020].

[4]- Dudley, D. (2020). "E-Commerce in a War Zone: How One Online Retailer in Libya is Building a Business in the Face of Turmoil".

https://www.forbes.com/sites/dominicdudley/2020/03/25/ecom merce-war-zone

libya/\#: :text=In\%20Libya\%2C\%20for\%20example\%2C\%20ju st,the $\% 20 \mathrm{UN}$ 's $\% 20$ trade $\% 20 \mathrm{arm} \% 20 \mathrm{UNCTAD}$ [Accessed: August, 2020].

[5]- Baldwin, R., and Mauro, B. W. d., (2020). "Economics in the Time of COVID-19: A new eBook". Centre for Economic Policy Research Press, London, UK.

[6]- Ohidujjaman., Hasan, M., Huda., M. N. (2013). "E-commerce challenges, solutions and effectiveness perspective Bangladesh". International Journal of Computer Applications, Vol. 70, No. 9, pp. 9-17.

[7]- Bairagi, A. K. (2011). "Utilization of E-Commerce can Change the Auction Culture of Bangladesh Specially in Public Sector". International Journal of Computer and Information Technology, Vol. 2, No. 1, pp. 55-61.

[8]- Ray, J. (2011). "Leveling E-commerce opportunities for developing countries". SSRN, pp. 1-20. doi: http://dx.doi.org/10.2139/ssrn.2108365.

[9]- Gilaninia, S., Danesh, S. Y. S., Amiri, M., Mousavian, S. J., Eskandarpour, B. (2011). "Effective factors on adoption of ecommerce in SME cooperative". Interdisciplinary Journal of Contemporary Research in Business, Vol. 3, No. 6, pp. 144-161.

[10]- European Commission. (2011). "Communication from the Commission to the European Parliament". the Council, the Economic and Social Committee and the Committee of the Regions. $\operatorname{COM}(2011) \quad 206$ final, Brussels, https://www.seldia.eu/images/pdf/CELEX_52011DC0206_EN_ TXT.pdf [Accessed: September, 2020].

[11]- Sumita, U., Zuo, J. (2010). "The impact of mobile access to the internet on information search completion time and customer conversion". Electronic Commerce Research and Applications, Vol. 9, No. 5, pp. 410-417.

[12]- Al-Shaikh, M., Torres, I. M., Zuniga, M. A., Ghunaim, A. (2010). "Internet commerce in Jordanian firms". Internet Commerce in Jordanian Firms, Vol. 9 No. 2, pp. 67-82.

[13]- Hamed, A. (2010). "E-commerce and Economic Development in Libya". P.h.D. Dissertation. University of Wales, Cardiff, England.

[14]- Zhou, T. and Zhang, S. (2009). "Examining the effect of ecommerce website quality on user satisfaction". In Proceedings of the 2nd International Symposium on Electronic Commerce and Security. IEEE, Nanchang, China, pp. 418-421.

[15]- Moftah, A. A. A., Abdullah, S. N. H. S. and Hawedi, H. S. (2012). "Challenges of security, protection and trust on E-commerce: A Case of Online Purchasing in Libya". International Journal of Advanced Research in Computer and Communication Engineering, Vol. 1, No. 3, pp. 141-145.
[16]- Avouris, N., Tselios, N., Fidas, C. and Papachristos, E. (2001). "Website evaluation: A usability-based perspective". In Proceedings of the 8th Panhellenic Conference on Informatics. Springer, Nicosia, Cyprus, pp. 217-231.

[17]- Flavián, C., Guinalíu, M. and Gurrea, R. (2006). "The role played by perceived usability, satisfaction and consumer trust on website loyalty". Elsevier-Information and Management, Vol. 43 No. 1, pp. 1-14.

[18]- Lee, Y. and Kozar, K. A. (2012). "Understanding of website usability: Specifying and measuring constructs and their relationships". Elsevier-Decision Support Systems, Vol. 52, No. 2, pp. 450-463.

[19]- El-fitouri, M. O. (2015). "E-Commerce in Developing Countries: A Case Study on the Factors Affecting E-commerce Adoption in Libyan Companies". International Journal of Engineering Research and Applications, Vol. 5, No. 1, pp. 102-115.

[20]- Consumers International. (2019). "Regional Briefing: Cybercrime in the Middle East and North Africa". England and Wales,

https://www.consumersinternational.org/media/314597/cybercri me-mena-briefing-dec2019.pdf, [Accessed: October, 2020].

[21]- Laudon, K. C. and Traver, C. G. (2018). "E-commerce 2017". Pearson, Boston, USA.

[22]- World Trade Organization. (2020). "E-commerce, Trade and the COVID-19 Pandemic". Geneva (2020). https://www.wto.org/english//tratop_e/covid19_e/ecommerce_re port_e.pdf, [Accessed: August, 2020].

[23]- Chang, E., Hussain, F. and Dillon, T. (2006). "Trust and reputation for service-oriented environments: technologies for building business intelligence and consumer confidence". John Wiley \& Sons, Chichester, UK.

[24]- Corbitt, B. J., Thanasankit, T. and Yi, H. (2003). "Trust and ecommerce: a study of consumer perceptions". Elsevier-Electronic commerce research and Applications, Vol. 2, No. 3, pp. 203-215.

[25]- Ahmed, A. A. and Hawedi, H. S. (2012). "Online Shopping and the Transaction Protection in E-Commerce: A Case of Online Purchasing in Libya". International Journal of Scientific and Research Publications, Vol. 2, No. 6, pp. 1-4.

[26]- European Commission. (2011). "Commission Staff Working Document".

https://ec.europa.eu/transport/sites/transport/files/modes/air/inter nal_market/doc/fitness_check_internal_aviation_market_en_co mmission_staff_working_document.pdf, [Accessed: August, 2020].

[27]- Tanner, J. and Raymond, M. A. (2012). "Marketing principles". Flat World Knowledge, Washington, USA.

[28]- Kotler, P. and Keller, K. L. (2006). "Identifying market segments and targets". Pearson Education, Singapore.

[29]- Armstrong, G., Adam, S., Denize, S., Volkov, M. and Kotler, P. (2014). "Principles of marketing". Pearson Australia, Melbourne, Australia.

[30]- Efendioglu, A. M., Yip, V. F. and Murray, W. L. (2005). "ECommerce in developing countries: issues and influences". In Proceedings of the 4th International Business and Economy Conference. Honolulu, Hawaii, pp. 10-15.

[31]- Dali, N. R. S. B. M., Harun, M. Z. M. B. N.R.S., Khalid, F. B. M. and Hamid, H. B. A. (2004). "E-Commerce in Islamic perspectives: The theoretical framework, key success factor and challenges for Islamic e-commerce business". In Proceedings of the Knowledge Management International Conference and Exhibition, Pinang, Malaysia, pp. 1-11.

[32]- Lawrence, J. E. and Tar, U. A. (2010). "Barriers to e-commerce in developing countries". Information, Society and Justice, Vol. 3, No. 1, pp. 23-35.

[33]- Abbad, M., Abbad, R. and Saleh, M. (2011). "Limitations of ecommerce in developing countries: Jordan case". Education, Business and Society: Contemporary Middle Eastern Issues, Vol. 4, No. 4, pp. 280-291.

[34]- Javalgi, R. G., Wickramasinghe, N., Scherer, R. F. and Sharma, S. K. (2005). "An assessment and strategic guidelines for developing e-commerce in the Asia-Pacific region". International Journal of Management, Vol. 22, No. 4, pp. 523-531. 
[35]- Faruk, U., Džemal, K. and Haris, H. (2019). "Estimates on Electronic Commerce Development in Bosnia and Herzegovina". International Journal of Sales, Retailing and Marketing, Vol. 8, No. 1, pp. 25-33.

[36]- European Commission. (2016). "Enhancing Access to, and the Use and Quality of ICT". Brussels (2016). https://s3platform.jrc.ec.europa.eu/documents/20182/84453/EN HANCING+ACCESS+TO $\% 2 \mathrm{C}+\mathrm{AND}+\mathrm{THE}+\mathrm{USE}+\mathrm{AND}+\mathrm{QU}$ ALITY+OF+ICT/70c4a2b7-7025-482a-bb99-7f7d9f6a6482, [Accessed: September, 2020].

[37]- Lawrence, J. E. (2002). "The use of the internet in small to medium-sized enterprises". P.h. D. Dissertation. University of Salford, Manchester, England.

[38]- Yu, E. (2020). "Singapore allows schools to resume Zoom use for home-based learning". https://www.zdnet.com/article/singapore-allows-schools-toresume-zoom-use-for-home-based-learning/, [Accessed: September, 2020].

[39]- Agarwal, S. and Bureau, E. (2017). "Internet users to touch 420 million by June 2017: IAMAI report". https://economictimes.indiatimes.com/tech/internet/420-millionto-access-internet-on-mobile-in-india-by-juneiamai/articleshow/58475622.cms, [Accessed: October, 2020].

[40]- Adriano, L. (2020). "Expert: Phishing attacks against workfrom-home employees are on the rise". https://www.insurancebusinessmag.com/ca/news/cyber/expertphishing-attacks-against-workfromhome-employees-are-on-therise-217178.aspx, [Accessed: October, 2020].

[41]- Gillis, A., Clark, C. (2020). "What is cybersecurity? Everything you need to know. Boston (2020). https://searchsecurity.techtarget.com/definition/cybersecurity, [Accessed: September, 2020].

[42]- Gallagher, S. and Brandt, A. (2020). "Facing down the myriad threats tied to COVID-19". Sophos Labs, Burlington (2020). https://news.sophos.com/en-us/2020/04/14/covidmalware/, [Accessed: October, 2020].

[43]- Lallie, H. S., Shepherd, L. A., Nurse, J. R. C., Erola, A., Epiphaniou, G., Maple, C. and Bellekens, X. (2020). "Cyber security in the age of covid-19: A timeline and analysis of cybercrime and cyber-attacks during the pandemic". arXiv:2006.11929 [cs.CR], Vol. 1, pp. 1-20.

[44]-Shi, F. (2020). "Threat Spotlight: Coronavirus-Related Phishing". $\quad$ https://blog.barracuda.com/2020/03/26/threatspotlight-coronavirus-related-phishing/, [Accessed: October, 2020].

[45]- Kumaran, N. and Lugani, S. (2020). "Protecting businesses against cyber threats during COVID-19 and beyond. Identity \& Security-Google

Cloud". https://cloud.google.com/blog/products/identitysecurity/protecting-against-cyber-threats-during-covid-19-andbeyond, [Accessed: October, 2020].

[46]- Macrynikola, N. and Miranda, R. (2019). "Active Facebook use and mood: when digital interaction turns maladaptive". ElsevierComputers in Human Behavior, Vol. 97, pp. 271-279.

[47]- Scarfone, K., Greene, J. and Souppaya, M. (2020). "Security for Enterprise Telework, Remote Access, and Bring Your Own Device (BYOD) Solutions". ITL Bulletin. https://csrc.nist.gov/CSRC/media/Publications/Shared/document s/itl-bulletin/itlbul2020-03.pdf, [Accessed: September, 2020].

[48]- Ringbeck, D., Seeberger, D. and Huchzermeier, A. (2019). "Toward Personalized Online Shopping: Predicting Personality Traits Based on Online Shopping Behavior". SSRN, pp.1-32.

[49]- Tagarev, T. and Sharkov, G. (2016). "Multi-stakeholder Approach to Cybersecurity and Resilience". Information and Security: An International Journal, Vol. 34, No. 1, pp. 59-68.

[50]- United Nations Office on Drugs and Crime (UNODC). (2020). "COVID-19: Cyber Threat Analysis". UNODC ROMENA, Vienna, Austria. https://www.unodc.org/documents/middleeastandnorthafrica/20 20/COVID19/COVID19_MENA_Cyber_Report_EN.pdf, [Accessed: October, 2020].
[51]- Cole, K., Chetty, M., LaRosa, C., Rietta, F., Schmitt, D. K. and Goodman, S. E. (2008). "Cybersecurity in africa: An assessment". Georgia Institute of Technology, Atlanta (2008). https://www.researchgate.net/profile/Seymour_Goodman/public ation/267971678_Cybersecurity_in_Africa_An_Assessment/lin ks/54e93dca0cf25ba91c7ef580/Cybersecurity-in-Africa-AnAssessment.pdf, [Accessed: September, 2020].

[52]- Kharouni, L. (2013). "Africa a new safe-harbor for cybercriminals". Trend Micro Incorporated, Cupertino (2013). https://www.trendmicro.nl/media/misc/africa-new-safe-harborfor-cybercriminals-en.pdf, [Accessed: October, 2020].

[53]- Kshetri, N. (2019). "Cybercrime and cybersecurity in Africa". Journal of Global Information Technology Management, Vol. 22, No. 2, pp. 77-81.

[54]- The Software Alliance. (2018). "Software Management: Security Imperative, Business Opportunity". BSA Global Software Survey, Washington DC (2018). https://gss.bsa.org/wpcontent/uploads/2018/05/2018_BSA_GSS_Report_en.pdf, [Accessed: September, 2020].

[55]- Hunaiti, Z., Masa'deh, R., Mansour, M. and Al-Nawafleh, A. (2009). "Electronic commerce adoption barriers in small and medium-sized enterprises (SMEs) in developing countries: the case of Libya". IBIMA Business Review, Vol. 2 No. 5, pp. 37 45.

[56]- Kemp, S. (2020). "Digital 2020 for Libya". Kepios, Singapore (2020). https://datareportal.com/reports/digital-2020-libya, [Accessed: August, 2020].

[57]- Nordea. (2020). "E-commerce in Libya". Export Entreprises, Helsinki (2020). https://www.nordeatrade.com/en/explore-newmarket/libya/e-commerce, [Accessed: August, 2020].

[58]- Turban, E., King, D., Lee, J., Warkentin, M. and Chung, M. (2006). "E-commerce: A managerial perspective". Pearson Prentice Hall, New Jersey, USA. 